\title{
Perubahan Profil Farmakokinetika Ibuprofen yang Diberikan dengan Kombinasi Vitamin C pada Tikus Putih (Rattus Norvegicus L.)
}

\author{
Sattrio Desrianto Prabowo, Arsyik Ibrahim, Riski Sulistiarini \\ Laboratorium Penelitian dan Pengembangan FARMAKA TROPIS \\ Fakultas Farmasi Universitas Mulawarman, Samarinda, Kalimantan Timur \\ email: sattriobowo@gmail.com
}

\begin{abstract}
ABSTRAK
Ibuprofen merupakan salah satu obat golongan NSAID (Non Steroid Anti-Inflamation Drug) yang secara luas digunakan oleh masyarakat sebagai antipiretik, analgesik, dan antiinflamasi. Vitamin C merupakan nutrisi penting bagi tubuh yang dikonsumsi secara luas oleh masyarakat untuk menjaga kesehatan. Penelitian awal menunjukkan bahwa terdapat pola akan kemungkinan teradinya interaksi antara vitamin $\mathrm{C}$ dengan obat golongan NSAID. Tujuan penelitian ini adalah mempelajari pengaruh vitamin $\mathrm{C}$ terhadap profil farmakokinetika ibuprofen. Uji dilakukan dengan membagi 9 ekor tikus dalam 3 kelompok (tiap kelompok 3 ekor). Tiap kelompok diberi perlakuan sebagai berikut: kontrol ibuprofen (ibuprofen 7,2 mg/200 gBB), dosis 1 (ibuprofen $7,2 \mathrm{mg} / 200 \mathrm{gBB}$ dan vitamin $\mathrm{C} 4,5$ $\mathrm{mg} / 200 \mathrm{gBB}$ ), dan dosis 2 (ibuprofen $7,2 \mathrm{mg} / 200 \mathrm{gBB}$ dan vitamin C $9 \mathrm{mg} / 200 \mathrm{gBB}$ ). Pengambilan cuplikan darah dilakukan dari vena ekor tikus pada menit ke- 15, 30, 45, 60, $75,90,120,180,240,300$ dan 360. Kadar ibuprofen dalam plasma diukur menggunakan spektrofotometer $U V$ - Vis pada panjang gelombang maksimum. Hasil penelitian menunjukkan bahwa vitamin $\mathrm{C}$ dapat mempengaruhi absorpsi ibuprofen dengan memperpanjang waktu konsentrasi plasma mencapai maksimum, menurunkan kadar maksimum ibuprofen dalam darah, dan vitamin $\mathrm{C}$ juga mempengaruhi eliminasi ibuprofen dengan memperpanjang waktu eliminasi ibuprofen
\end{abstract}

Kata Kunci: Ibuprofen, Vitamin C, Farmakokinetik

\begin{abstract}
Ibuprofen is one of the NSAID (NonSteroid Anti Inflamation Drug) drugs that has been widely used as antipyretic agent, analgesic dan anti-inflamation. Vitamin $C$ is an important nutrient for the body and has been widely used to maintain health. Earlier study indicate patterns of interaction between vitamin $C$ and NSAID drugs. The aims of this research were to study the influence of vitamin $C$ to the pharmacokinetics profile of ibuprofen. The study was conducted using 9 rats rats, divided into 3 groups ( $n=3$ per group). Each group was treated the following treatment : control ibuprofen (ibuprofen 7.2 $\mathrm{mg} / 200 \mathrm{gBW}$ ), dose 1 group (ibuprofen 7,2 $\mathrm{mg} / 200 \mathrm{gBW}$, and vitamin $C 4,5 \mathrm{mg} / 200 \mathrm{gBW}$ ), and dose 2 group (ibuprofen 7,2 $\mathrm{mg} / 200 \mathrm{gBW}$ and vitamin $C 9 \mathrm{mg} / 200 \mathrm{gBW}$ ). Blood sampling is done from the vein of rat's tail at minutes 15, 30, 45, 60, 75, 90, 120, 180, 240, 300 and 360. The quantitation of ibuprofen in plasma was determined by UV spectrophotometer at maximum wavelength. Result showed that vitamin $C$ changed the absorption of ibuprofen by prolonged the maximum plasma concentration time, reduce
\end{abstract}


maximum levels of ibuprofen and vitamin $C$ also changed the elimination of ibuprofen by prolonged the elimination time.

Keywords: Ibuprofen, Vitamin C, Pharmacokinetics

\section{PENDAHULUAN}

Farmakokinetik menggambarkan perjalanan waktu obat dalam darah dengan persamaan matematika sehingga kinerja bentuk sediaan farmasi dapat dievaluasi dalam hal tingkat dan jumlah obat yang diberikan ke dalam darah, dan menyesuaikan rejimen dosis obat untuk memproduksi dan mempertahankan konsentrasi darah pada indeks terapi[2]. Ibuprofen merupakan salah satu obat golongan NSAID (Non Steroid AntiInflamation Drug) yang sering digunakan sebagai antipiretik, analgesik, dan antiinflamasi[1]. Vitamin $\mathrm{C}$ adalah nutrisi dan vitamin yang larut dalam air dan penting untuk kehidupan serta untuk menjaga kesehatan yang secara luas digunakan oleh masyarakat[4]. Beberapa penelitian awal menunjukkan bahwa terdapat pola akan kemungkinan teradinya interaksi antara vitamin $\mathrm{C}$ dengan obat golongan NSAID[8]. Interaksi vitamin $\mathrm{C}$ dengan NSAID menunjukkan sinergisitas dengan efek anti inflamasi dan mampu melindungi lambung dari kemungkinan terjadinya luka lambung. Serta, NSAID dapat menurunkan kadar simpanan vitamin $\mathrm{C}$ dalam tubuh[3].

Tujuan penelitian ini adalah mempelajari pengaruh vitamin $\mathrm{C}$ terhadap profil farmakokinetika ibuprofen.

\section{METODOLOGI PENELITAN}

\section{Bahan}

Bahan yang diteliti adalah ibuprofen murni (PT. Brataco®), dan asam askorbat murni (PT. Brataco®). Bahan penelitian yang digunakan adalah aquadest, etanol p.a, dan ethylenediamintetraacetat acid (EDTA).

\begin{abstract}
Alat
Alat-alat yang digunakan adalah alat kaca laboratorium yang mendukung (Pyrex $\left.{ }^{\circledR}\right)$, timbangan analitik, timbangan hewan uji, kandang hewan uji, spuit oral $3 \mathrm{~mL}$ dan $5 \mathrm{~mL}$, spektrofotometer UVVIS (Double Beam Spechtrophotometer), Centrifuge PLC Series (PLC-03 Top Centrifuge), mikropipet, pisau cukur, holder, vakuntainer, gunting bedah, mikrotip, microtube (Eppendrof®), dan vortex mixer (Maxi Mix II ).
\end{abstract}

\section{Hewan Uji}

Hewan yang digunakan ialah tikus putih yang diperoleh dari Laboratorium Farmakologi Universitas Gajah Mada berumur 4-6 bulan. Hewan coba diaklimitasi selama 14 hari dalam kandang hewan dengan pemberian pakan standar dan air minum.

Kemudian dikelompokan menjadi 3 kelompok dengan 3 ekor utuk masing-masing kelompoknya. Kelompok 1 sebagai kontrol ibuprofen, kelompok 2 sebagai dosis 1, dan kelompok 3 sebagai dosis 2 .

\section{Prosedur}

\section{Penetapan Pemberian Dosis Vitamin C dan Ibuprofen}

Ibuprofen dosis yang digunakan adalah $400 \mathrm{mg}$. Vitamin $\mathrm{C}$ dibuat dalam 3 variasi dosis yaitu $250 \mathrm{mg}$, dan $500 \mathrm{mg}$. Dilakukan perhitungan konversi dosis manusia ke dosis tikus. 


\section{Validasi Metode}

\section{Penetapan Panjang Gelombang Maksmimum}

Ditimbang ibuprofen murni sebanyak $10 \mathrm{mg}$ dan di larutkan dengan etanol p.a $100 \mathrm{~mL}$ dalam gelas kimia, larutan dimasukkan ke dalam labu takar $100 \mathrm{~mL}$ kemudian ditambahkan etanol p.a hingga $100 \mathrm{~mL}$ dan diperoleh larutan induk baku ibuprofen dengan kadar 100 $\mathrm{mg} / 100 \mathrm{~mL}$ atau setara dengan 1000 ppm. Dibuat variasi konsentrasi ibuprofen dengan kadar 10 ppm, 25 ppm dan $60 \mathrm{ppm}$ dari larutan stok ibuprofen, lalu diukur serapannnya pada panjang gelombang $200 \mathrm{~nm}$ sampai $300 \mathrm{~nm}$.

\section{Pembuatan Kurva Baku Ibuprofen}

Dibuat variasi konsentrasi sebesar 10, 15, 25, 40 dan 60 ppm, dari larutan stok iboprofen. Lalu dibaca serapan pada panjang gelombang maksimum.

\section{Linieritas dan Rentang}

Dihitung persamaan regresi linear Ibuprofen menggunakan model persamaan $\mathrm{y}=\mathrm{bx}+\mathrm{a}$.

\section{Uji Akurasi}

Dilakukan sebanyak dua kali yaitu uji akurasi pada sampel tanpa preparasi dan pada sampel yang melalui proses preparasi. Uji akurasi sampel tanpa preparasi dilakukan dengan cara membuat seri konsentrasi larutan baku ibuprofen 10, 15, 25, 40 dan 60 ppm, kemudian diukur serapannya menggunakan spektrofotometer UV-VIS, masing-masing seri konsentrasi di replikasi sebanyak 3 kali.

Uji akurasi pada sampel yang melalui proses preparasi dilakukan dengan cara membuat larutan baku ibuprofen 10, 15, 25, 40 dan 60 ppm, yang kemudian dipreparasi sesuai dengan prosedur penetapan kadar ibuprofen dalam darah yang digunakan pada penelitian ini. Masing-masing seri konsentrasi direplikasi sebanyak 3 kali.

\section{Uji Presisi}

Dihitung nilai koefisien variasi dari kadar parasetamol yang diperoleh dari hasil uji akurasi.

\section{Penetapan Jadwal Pengambillan Cuplikan}

Dua ekor tikus dipuasakan selama 18 jam kemudian diberi larutan ibuprofen dosis tunggal $400 \mathrm{mg}$ yang telah dikonversi sesuai hewan uji yang digunakan. Cuplikan darah diambil pada waktu ke- $1,2,3, \ldots, \mathrm{n}$ melalui vena ekor tikus. Cuplikan sampel darah tiap waktu diberi perlakuan sesuai dengan prosedur penetapan kadar ibuprofen dalam darah yang digunakan pada penelitian ini. Setelah itu, ditetapkan nilai $\mathrm{t}_{1 / 2}$ untuk penetapan jadwal sampling pengujian.

\section{Pengujian Perlakuan dan Penetapan Kadar Ibuprofen dalam Darah}

Hewan uji dipuasakan selama 18 jam, kemudian diberikan ibuprofen tunggal secara oral sebanyak $400 \mathrm{mg}$ yang telah dikonversi dosis. Hewan uji pada kelompok 1 yaitu untuk kontrol positif hanya diberikan obat ibuprofen dan untuk kontrol negatif tidak diberikan ibuprofen, sedangkan hewan uji pada kelompok uji yaitu dosis 1 dan dosis 2 , setelah pemberian ibuprofen, hewan uji diberikan vitamin $\mathrm{C}$ secara oral sesuai dosis konversi dari manusia ke hewan uji pada $250 \mathrm{mg}$, dan $500 \mathrm{mg}$.

Pengambilan sampel darah dilakukan dari vena ekor tikus pada waktu sesuai hasil penetapan jadwal pengambilan cuplikan darah, lalu darah hewan uji ditampung di dalam tabung berisi EDTA, lalu disentrifugasi selama 5 menit kecepatan $2500 \mathrm{rpm}$, diambil plasmanya. Plasma ditambahkan dengan etanol p.a kemudian divortex, dan disentrifus selama 8 menit kecepatan 3000 rpm. Diambil bagian plasmanya, 
diukur absorbansi larutan dengan menggunakan alat spektrofotometer UV pada panjang gelombang maksimum. Dari data absorbansi, dihitung kadar ibuprofen pada tiap cuplikan waktu menggunakan persamaan regresi linear kurva baku ibuprofen.

\section{Pembuatan Profil Kadar Ibuprofen dalam Darah}

Berdasarkan data darah yang didapat dari setiap waktu, dapat dibuat suatu kurva Log konsentrasi plasma (Cp) terhadap waktu (t). Konsentrasi plasma sebagai sumbu y dan waktu sebagai sumbu- $x$.
HASIL DAN PEMBAHASAN

\section{Penetapan Pemberian Dosis Vitamin C dan Ibuprofen}

Dosis vitamin $\mathrm{C}$ dan ibuprofen setelah dilakukan konversi dosis manusia ke dosis tikus dapat dilihat pada tabel 1 .

\section{Penetapan Panjang Gelombang Maksmimum \\ Hasil penetapan panjang} gelombang maksimum dapat dilihat pada gambar 1. Panjang gelombang yang menunjukkan serapan maksimum adalah $235 \mathrm{~nm}$. Panjang gelombang yang diperoleh tidak berbeda jauh dengan panjang gelombang maksimum yang ada diliteratur yaitu pada $230 \mathrm{~nm}$ [5], sehingga panjang gelombang ini ditetapkan sebagai panjang gelombang maksimum.

Tabel 1. Dosis Pemberian Vitamin C dan Ibuprofen

\begin{tabular}{lll}
\hline & Dosis Manusia & Dosis Tikus \\
\hline Ibuprofen & $400 \mathrm{mg}$ & $7.2 \mathrm{mg} / 200 \mathrm{gBB}$ \\
Vitamin C Dosis 1 & $250 \mathrm{mg}$ & $4.5 \mathrm{mg} / 200 \mathrm{gBB}$ \\
Vitamin C Dosis 2 & $500 \mathrm{mg}$ & $9 \mathrm{mg} / 200 \mathrm{gBB}$ \\
\hline
\end{tabular}

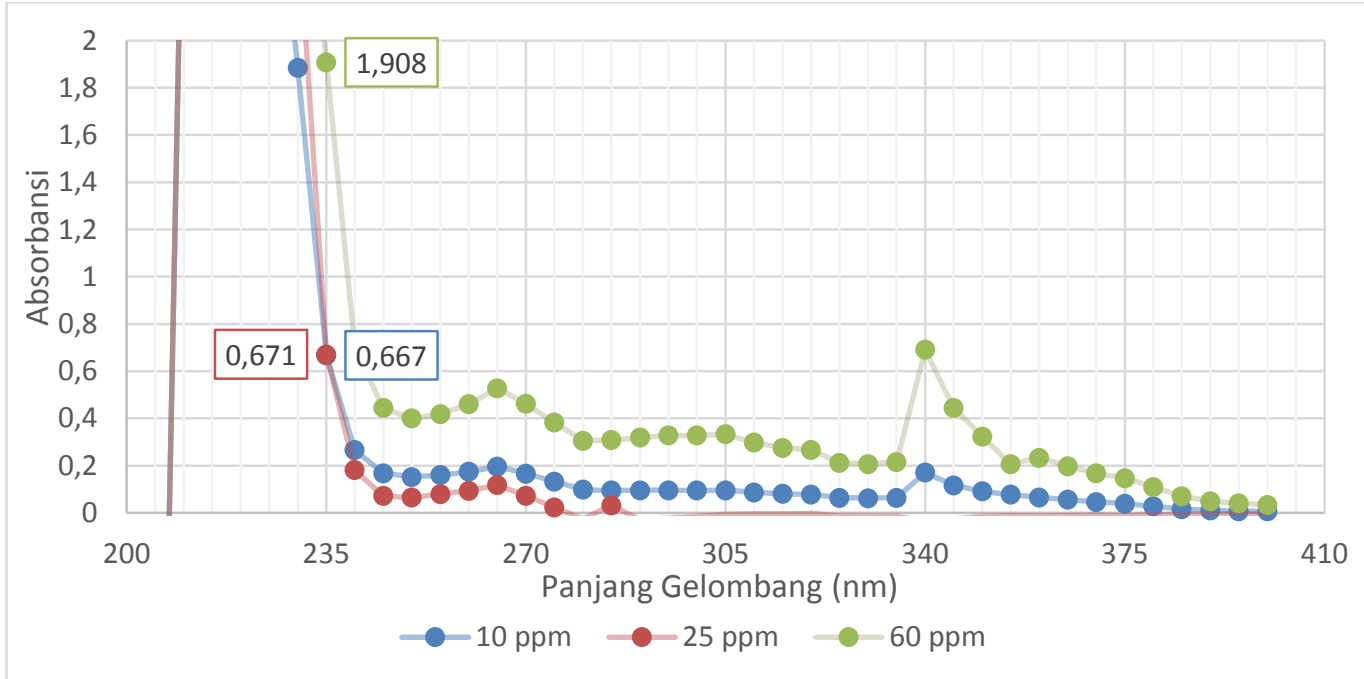

Gambar 1. Kurva Absorpsi Ibuprofen 


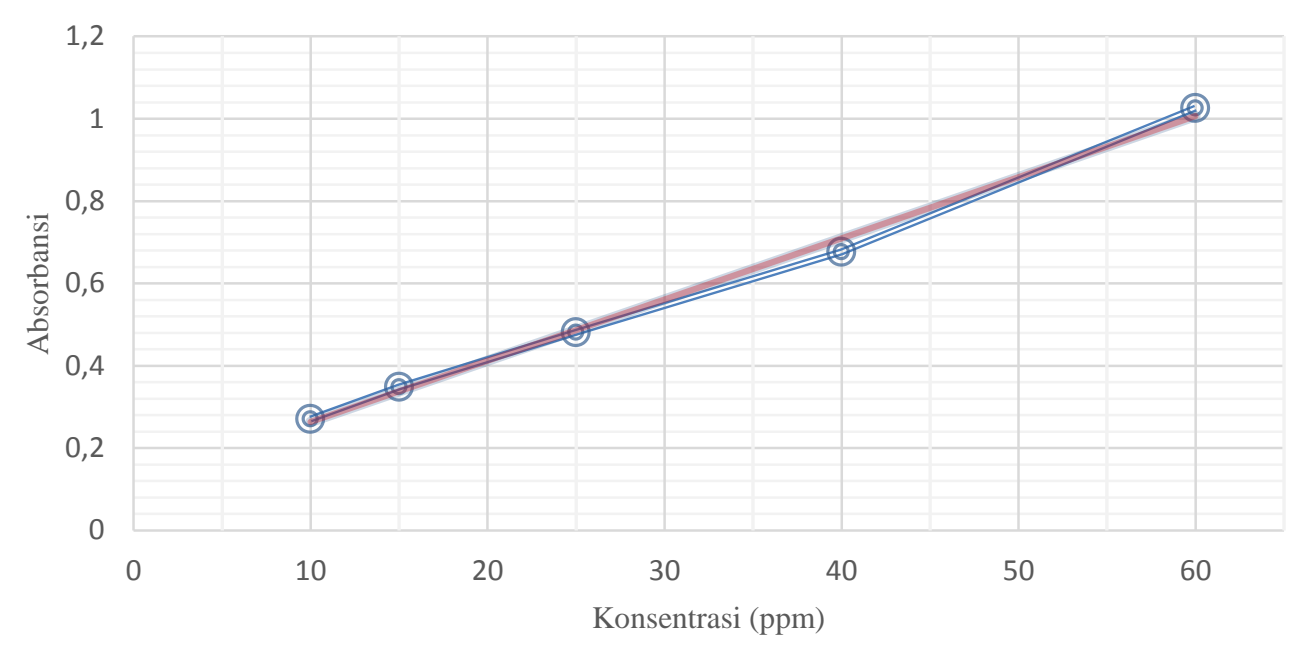

Gambar 2. Kurva Baku Ibuprofen

Tabel 2. Hasil Uji Akurasi

\begin{tabular}{ccc}
\hline Parameter Uji Akurasi & $\begin{array}{c}\text { Sampel tanpa } \\
\text { Preparasi }\end{array}$ & $\begin{array}{c}\text { Sampel dengan } \\
\text { preparasi }\end{array}$ \\
\hline Recovery Rata-Rata & $100.988 \%$ & $96.801 \%$ \\
Kesalahan SIstemik Rata-Rata & $0.988 \%$ & $3.199 \%$ \\
\hline
\end{tabular}

\section{Pembuatan Kurva Baku Ibuprofen}

Nilai absorbansi yang diperoleh dari tiap konsentrasi berada pada kisaran rentang 0,2-0,8. Nilai absorbansi kurva baku yang diperoleh telah memenuhi hukum Lambeert-Beer dimana pada kisaran absorbansi tersebut kesalahan pengukuran yang terjadi adalah yang paling minimal. Kurva baku Ibuprofen dapat dilihat pada gambar 2 .

\section{Linieritas dan Rentang}

Persamaan regresi linier dari kurva baku ibuprofen yang diperoleh adalah $\mathrm{y}=0.01486 \mathrm{x}+0.11426$ dengan nilai koefisien korelasi atau $\mathrm{R}$ sebesar 0,99769. Menurut literatur nilai $\mathrm{R}>0,9$ 1 diketahui memiliki hubungan antarvariabel sangat tinggi, kuat dan dapat diandalkan[6]. Oleh sebab itu, persamaan garis kurva baku ini dapat digunakan untuk menetapkan kadar ibuprofen dalam sampel darah.

\section{Uji Akurasi}

pada tabel 2 .

Hasil uji akurasi dapat dilihat

Nilai recovery yang baik adalah diatas $90 \%$ dan untuk suatu metode yang harus melalui proses preparasi sampel yang cukup panjang misalnya dengan ekstraksi, maka recovery yang dicapai hendaknya tidak kurang dari $75 \%$, sedangkan nilai kesalahan sistematik suatu metode hendaknya tidak lebih dari 20\%[7]. Sehingga, nilai recovery dan kesalahan sistematik rata-rata sampel tanpa preparasi dan sampel dengan preparasi telah memenuhi syarat uji akurasi.

\section{Uji Presisi}

Hasil uji presisi dapat dilihat pada tabel 3 . 
Tabel 3. Hasil Uji Presisi

\begin{tabular}{ccc}
\hline Parameter Uji Presisi & $\begin{array}{c}\text { Sampel tanpa } \\
\text { Preparasi }\end{array}$ & $\begin{array}{c}\text { Sampel dengan } \\
\text { Preparasi }\end{array}$ \\
\hline Kesalahan Acak Rata-Rata & $0.0977 \%$ & $0.268 \%$ \\
\hline
\end{tabular}

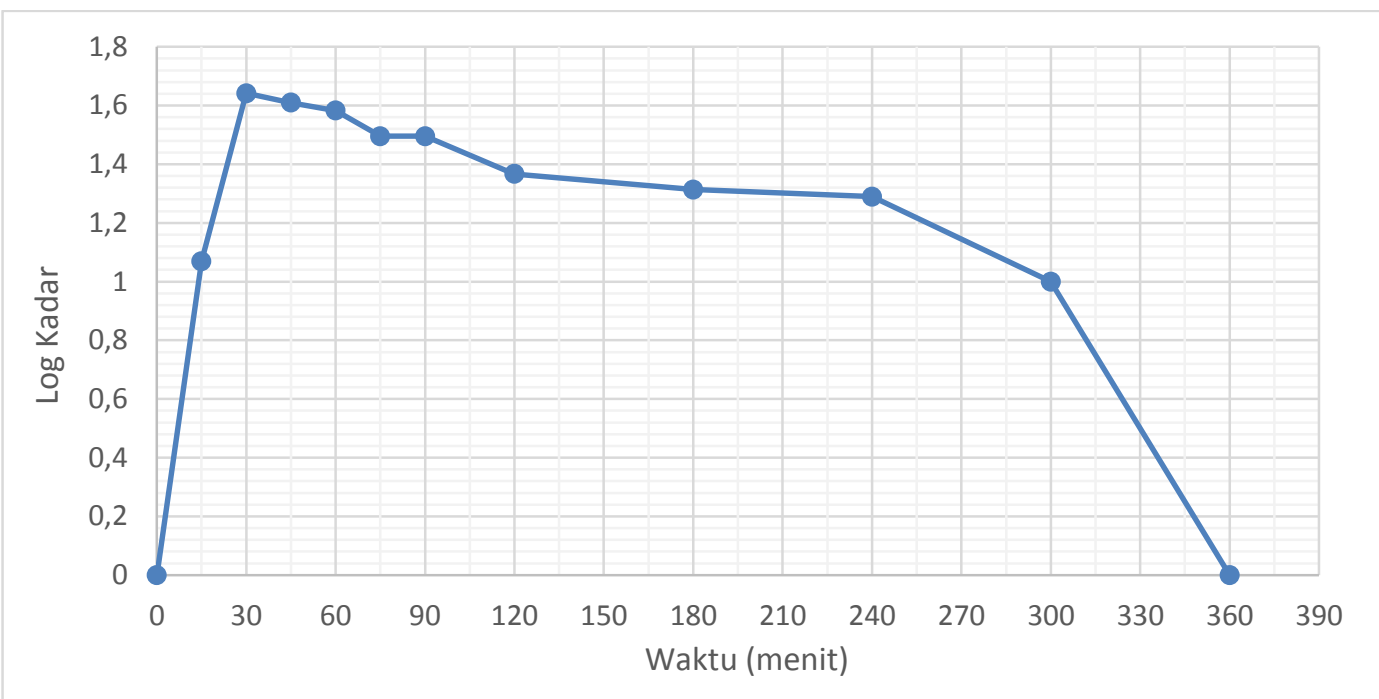

Gambar 3. Kurva Log kadar Ibuprofen dalam Darah vs Waktu

Hasil uji presisi dinyatakan sebagai kesalahan acak. Kesalahan acak yang baik harus kurang dari 20\%[9]. Berdasarkan hasil yang diperoleh dapat disimpulkan bahwa kesalahan acak ratarata telah memenuhi syarat uji presisi.

\section{Penetapan Jadwal Pengambillan Cuplikan}

Hasil penetapan jadwal pengambilan cuplikan dapat dilihat pada gambar 3 .

Hasil yang diperoleh menunjukkan bahwa $\mathrm{t}_{1 / 2}$ rata-rata ibuprofen adalah sebesar 80.45572 menit. Hasil perhitungan 4 dan 5 kali $\mathrm{t}_{1 / 2}$ rata-rata ratarata ibuprofen diperoleh waktu minimal pengambilan cuplikan darah selama 321.82288 menit atau 5.36372 jam dan 402.2786 menit atau 6.70464 jam. Sehingga waktu pengambilah cuplikan darah yang digunakan adalah selama 360 menit atau 6 jam. Hal ini sesuai dengan syarat pengambilan cuplikan darah yaitu $3-5$ kali t $_{1 / 2}$ obat [7].

\section{Pengujian Perlakuan dan Penetapan Kadar Ibuprofen dalam Darah}

Darah tikus yang diperoleh ditampung dalam microtube yang berisi EDTA. EDTA berfungsi sebagai antikoagulan yang akan membentuk kompleks kalsium-EDTA. Hal ini akan menghambat pembekuan darah karena kalsium merupakan salah satu faktor pembekuan darah. Selanjutnya plasma darah yang diperoleh ditambahkan dengan etanol. Etanol berfungsi sebagai pengendap protein. Etanol akan menurunkan konstanta dielektrik larutan yang menyebabkan penurunan kelarutan sehingga terjadi pengendapan protein. Selain itu etanol juga berfungsi untuk mengekstraksi ibuprofen, karena ibuprofen mudah larut dalam etanol.

Setelah seluruh proses preparasi selesai, sampel diukur absorbansinya 
menggunakan spektrofotometer UV pada panjang gelombang $235 \mathrm{~nm}$, dari nilai absorbansi yang diperoleh dapat dihitung kadar ibuprofen pada setiap sampel. Kadar ibuprofen dalam setiap perlakuan dapat dilihat pada tabel 4 .

\section{Profil Farmakokinetika Ibuprofen}

Profil farmakokinetika ibuprofen tiap kelompok uji dapat diamati pada gambar 4.

Tabel 4. Hasil Perlakuan dan Penetapan Kadar Ibuprofen dalam Darah

\begin{tabular}{cccccccc}
\hline & \multirow{2}{*}{ No } & \multicolumn{3}{c}{ Kadar Ibuprofen $(\mathrm{ppm})$} & \multicolumn{3}{c}{ Log Kadar Ibuprofen } \\
\cline { 3 - 8 } & (menit) & $\begin{array}{c}\text { Kontrol } \\
\text { Ibuprofen }\end{array}$ & Dosis 1 & Dosis 2 & $\begin{array}{c}\text { Kontrol } \\
\text { Ibuprofen }\end{array}$ & Dosis 1 & Dosis 2 \\
\hline 1 & 0 & 0 & 0 & 0 & 0 & 0 & 0 \\
2 & 15 & 11,72907 & 22,04437 & 15,26094 & 1,06926 & 1,34329 & 1,18358 \\
3 & 30 & 43,85227 & 25,18381 & 19,97010 & 1,64199 & 1,40112 & 1,30038 \\
4 & 45 & 40,71283 & 29,16418 & 21,25951 & 1,60973 & 1,46486 & 1,32755 \\
5 & 60 & 38,24613 & 21,65194 & 23,44591 & 1,58259 & 1,33549 & 1,37007 \\
6 & 75 & 31,29451 & 25,12775 & 24,51108 & 1,49547 & 1,40015 & 1,38936 \\
7 & 90 & 31,29451 & 20,97921 & 25,01563 & 1,49547 & 1,32179 & 1,39821 \\
8 & 120 & 23,27773 & 21,48376 & 25,68837 & 1,36694 & 1,33211 & 1,40974 \\
9 & 180 & 20,58678 & 18,51250 & 22,82923 & 1,31359 & 1,26747 & 1,35849 \\
10 & 240 & 19,46555 & 15,87761 & 19,18524 & 1,28927 & 1,20079 & 1,28297 \\
11 & 300 & 9,991166 & 21,87619 & 18,56857 & 0,99962 & 1,33997 & 1,26878 \\
12 & 360 & $-0,66051$ & 13,13061 & 12,56999 & 0 & 1,11829 & 1,09933 \\
\hline
\end{tabular}

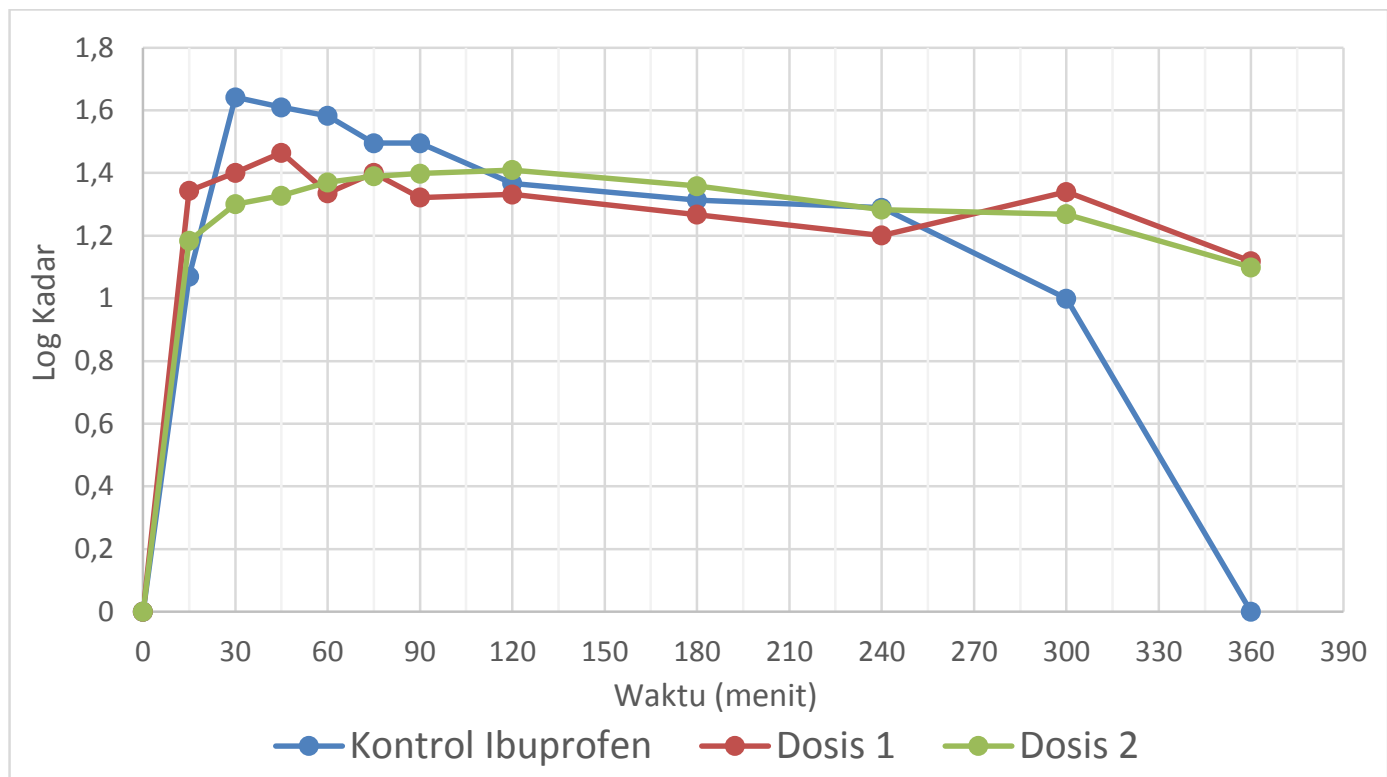

Gambar 4. Kurva Log Kadar Ibuprofen dalam Darah vs Waktu tiap Kelompok Uji 
Kadar ibuprofen dalam darah pada kontrol positif mulai teramati pada menit ke-15, dan mencapai kadar maksimum pada menit ke-30. Selanjutnya, kadar ibuprofen dalam darah mulai berkurang pada menir ke-45, dan pada menit ke-360 kadar ibuprofen dalam darah sudah tidak teramati.

Kadar ibuprofen dalam darah pada dosis1 dan dosis 2 mulai teramati pada menit ke-15, dan mencapai kadar maksimum pada menit ke-45 untuk dosis 1, dan menit ke-120 untuk dosis 2. Selanjutnya, kadar ibuprofen dalam darah mulai berkurang pada menit ke-60 untuk dosis 1, dan menit ke-180 untuk dosis 2 . Namun, kadar ibuprofen dalam darah pada dosis 1 dan dosis 2 meningkat pada menit ke-300, yang diikuti penurunan kadar ibuprofen dalam darah pada menit ke 360 .

Kontrol ibuprofen, dosis 1 dan dosis 2 menunjukkan pola absorpsi yang sama, yaitu kadar ibuprofen dalam darah mulai teramati pada menit ke-15. Namun, kadar maksimum ibuprofen dalam darah pada kontrol ibuprofen lebih tinggi dari pada dosis 1 dan dosis 2 . Hal ini diduga disebabkan karena adanya interaksi pada proses absorpsi. Pemberian vitamin $\mathrm{C}$ yang bersifat asam dapat menurunkan $\mathrm{pH}$ lambung. Ibuprofen bersifat basa lemah sehingga fraksi ibuprofen lebih banyak dalam bentuk terionisasi. Fraksi ibuprofen yang terionisasi bersifat hidrofilik, sehingga proses absorpsi ibuprofen menjadi terhambat.

Kontrol ibuprofen menunjukkan kadar maksimum ibuprofen dalam darah pada menit ke-30, sedangkan dosis 1 pada menit ke-45, dan dosis 2 pada menit ke-120. Hal ini diduga disebabkan karena waktu pengosongan lambung menuju usus halus diperpanjang, karena bertambahnya volume lambung akibat pemberian iburofen secara kombinasi dengan vitamin C. Ibuprofen lebih banyak diabsorpsi di usus, karena kondisi
$\mathrm{pH}$ usus yang basa menyebabkan fraksi obat lebih banyak dalam bentuk tak terionisasi yang bersifat lipofilik

Kontrol ibuprofen menunjukkan kadar ibuprofen dalam darah mulai berkurang pada menit ke-45, dosis 1 pada menit ke-60, dan dosis 2 pada menit ke180. Kontrol ibuprofen, dosis 1, dan dosis 2, menunjukkan pola eliminasi yang sama hingga menit ke-240. Namun, pada kontrol ibuprofen kadar ibuprofen dalam darah sudah tidak teramati pada menit ke360. Sedangkan pada dosis 1 dan 2, kadar ibuprofen dalam darah meningkat pada menit ke-300, yang diikuti penurunan kadar ibuprofen dalam darah pada menit ke 360. Hal ini diduga disebabkan karena pada menit ke-300 proses absorpsi pada dosis 1 dan dosis 2 masih berlangsung, karena fraksi ibuprofen masih ada yang belum diabsorpsi. Sedangkan pada kontrol ibuprofen kadar ibuprofen sudah mengalamai proses eliminasi.

\section{KESIMPULAN}

Hasil penelitian menunjukkan bahwa vitamin $\mathrm{C}$ dapat mempengaruhi absorpsi ibuprofen dengan memperpanjang waktu konsentrasi plasma mencapai maksimum, dan menurunkan kadar maksimum ibuprofen dalam darah. Vitamin $\mathrm{C}$ juga dapat mempengaruhi eliminasi ibuprofen dengan memperpanjang waktu eliminasi ibuprofen.

\section{DAFTAR PUSTAKA}

1. Bushra, R., dan Aslam, N. 2010. An Overview of Clinical Pharmacology of Ibuprofen. Oman Media Journal, 25 (3).

2. Florence, Alexender T., dan Siepmann, Juergen. 2009. Modern Pharmaceutics, Fifth Edition, Volume 1, Basic Principles and Systems. United States of America: Informa Health Care Incorporation. 
3. Hechtman, Leah. 2012. Clinical Naturopathic Medicine. Churchcill Livingston : Australis

4. Naidu, K. A. 2003. Vitamin C in human health and disease is still a mystery? An overview. Nutrition Journal, Volume 2, Nomor 7.

5. Sarah, Rikha. 2009. Pemeriksaan Ketersediaan Hayati dari Tablet Ibuprofen pada Hewan Kelinci. Universitas Sumatera Utara: Medan.

6. Sarwono, J. 2010. Pintar Menulis Karya Ilmiah-Kunci Sukses dalam Menulis Ilmiah. CV Andi OFFSET: Yogyakarta.

7. Simaremare, Pinondang R. P. 2013. Pengaruh Jus Buah Durian (Durio
Zibethinus murr.) terhadap Profil Farmakokinetik Parasetamol pada Tikus Putih (Rattus norvegicus L.) Jantan Galur Wistar. Pontianak: Universitas Tanjung Pura.

8. Stargrove, Mitchell Bebel, dan Stargrove, Lori Beth. 2012. Herb, Nutrient, and Drug Interaction. Mosby: USA

9. U.S Department of Health and Human Services. 2001. Guidance for Industry, Bioanalytical Method Validation. U.S Department of Health and Human Services, 